\title{
The Impact of Services Quality on Brand Experiences: The Mediating Role of Customer Engagement
}

\author{
Firman $^{1 *}$, M. Sargio Saldino ${ }^{2}$ \\ 1, 2 Universitas Negeri Padang, Padang, Indonesia \\ *Corresponding author. Email: firmanfeunp@gmail.com
}

\begin{abstract}
The primary purpose of this study is to analyze: (1) The impactof Services Quality on Customer Engagement, (2) The impactof Services Quality on Brand Experiences, (3) The impactof Services Quality on Brand Exeriences through Customer Engagement, (4) The impactof Customer Engagement on Brand Experiences.This research using causative researchwith total sample was 151 people by using questionnaire. The result of study showed that (1) Services Quality has significant effect on Customer Engagement, (2) Services Quality has no effect on Brand Experiences, (3) Services Quality has significant effect on Brand Experiences trhough Customer Engagement, (4) Customer Engagement has significant effect on Brand Experiences.
\end{abstract}

Keywords: Services quality, customer engagement, brand experiences, KFC.

\section{INTRODUCTION}

Along with the global progress, human beings have a more diverse ways to the fulfilment of their needs [1]. Such as general needs where there is a need for breathing, food, drink and others. In fulfilling needs such as eating and drinking, many goods and service companies offer a wide selection of products according to human desires, this is what restaurants do, which makes people today to fulfil their basic needs accompanied by high human desires.

There are several classification groups of restaurants, one of which is fast food restaurants, which exist due to changes in the diverse consumption patterns of the community which give rise to a practical food serving concept [2]. This business opportunity is of course a new opportunity for many capital owners to take part in the fast food restaurant industry. PT. Fast Food Indonesia, Tbk is a company engaged in the management of fast food restaurants in Indonesia which has the rights to the Kentucky Fried Chicken (KFC) trademark.

Some fast food companies are starting to use a brand-oriented strategy, because of the very tight competition in the fast food restaurant industry, one of which is Brand Experience. Brand experience, where the consumer's experience will last, consumers persist in a strong circle in consuming products due to the experience they feel [3]. Therefore, it is not only functional brand experiences that need to be achieved, but hedonic and symbolic brand experiences must also be appropriate [4]. The scope of Customer Engagement is limited to the focus on or the dynamics within the interaction.

Regardless, Customer Engagement and Brand Experiences both fit within a relational paradigm centred on optimizing customer interaction or perspective of the customer and the company [5].Several previous studies have argued that Customer Engagement can produce Brand Experiences [6]. Brand Experiences can be created through a positive sensor arising from stimuli given to customers through a more compelling and interesting that engage customers with the brand. The customer experience will be more interesting if there is more customer involvement in the brand, of course [7].

Over time, the focus on customer engagement interactions increases with certain brand experiences. Customer Engagement has special relevance in the context of service and the interactive nature of interactivity with their customers towards the brand is 
stated that there are four indicators that can affect brand experiences, namely: Product Quality, Store Image, Promotion and Service Quality. Based on the background of the problem above, the authors are interested in discussing this further in research with the title: the impact of services quality on brand experiences :the mediating role of customer engagement.

\subsection{Brand Experiences}

Brand experiences are defined as sensations, feelings, cognitions and consumer responses generated by brands, related to the stimuli generated by the brand design, brand identity, marketing communications, people and the brand's environment [3]. Brand Experiences are not limited to the experiences that happened just once, but repeatedly involve a different experience in a different phase of before, during and after consumption or penggunanaa [8].

Consumers can experience Brand Experiences directly and indirectly. Directly, consumers can experience Brand Experiences after consumers consume the products or services offered by the brand, while indirectly consumers will be able to experience Brand Experiences after seeing advertisements or other marketing strategies carried out by these brands related to the products or services they offer and when consumers look for products, once they save and get hold of services, and once they devour them[3]. there are fourdimensions of Brand Experiences, particularly Sensory, Affection, Behavior, and Intellectual.

\subsection{Services Quality}

Services Quality is described as a form of attitude, because it is a global assessment of the superiority of services provided by the company. Services Quality has been the point of interest of many research that show that Service Quality gives a aggressive benefit for a company. Service Quality withinside the literature of Service Marketing frequently displays to purchaser perceptions and tests of a product or service [10].

Services quality is broadly recognized as the influence of behavioral intentions and customer satisfactionthat lead to company profitability [11]. Other researcher say a few researchers assert that carrier nice need to be assessed through a contrast among perceptions and expectations. Others [12] argue that customer perceptions of employee performance against each of these service encounters determine the company's Services Quality. there are five main indicators of Service Quality, namely Tangible, Reliability, Responsiveness, Assurance, and Emphaty.

\subsection{Customer Engagement}

Customer Engagement is a personal relationship between customers and brands as a manifestation of cognitive, affective and behavioral responses outside of purchasing activities.Customer Engagement refers to the relationship between customers and Brand Styles can be applied using the style palette available within the template. To activate it the press Ctrl+Shift+s. Apply the style as required based on the content and context. (Please don't highlight your text in yellow.) Experiences [3], Customer Engagement discusses cognitive , emotional, and / or consumer behavior during their interactions with brands [7]. Customer Engagement has a long-term impact such as consumer trust, so that consumers are not only involved and experience intense relationships with service product providers [6].

Based on the explanation of Customer Engagement, it can be concluded that Customer Engagement is the intensity of a consumer's participation with a product that concerns the aspects of consumer involvement, experience, trust and emotion. there are 3 indicators in measuring Customer Engagement, namely Cognitive Processing, Affection and Activation.

\subsection{Conceptual Framework \& Hipothesis}

To make it easier to answer the research objectives, based on the problems and theoretical basis above, the conceptual framework of this research is:

Accordance with the problems and conceptual framework stated above, the following hypothesis are formulated:

1. Services Quality has a significant effect on Customer Engagement with KFC customers in Padang City.

2. Services Quality has a significant effect on Brand Experiences with KFC customers in Padang City.

3. Services Quality has a significant effect on Brand Experiences mediated by Customer Engagement with KFC customers in Padang City.

4. Customer Engagement has a significant effect on Brand Experiences with KFC customers in Padang City.

\section{METHOD}

The type of research to be carried out is classified as causative research. The research was conducted in the cityof Padang and was carried out in July 2019 until it was completed. The sampling method is non probability sampling method with purposive sampling technique. Sampling is based on considerations of KFC consumers who are in the city of Padang and who have spent at least two KFC outlets in the past year.Researchers used the Cochran formula to decide the sample size on this 
studywith a total sample of 151 people. Types and sources of data in this research use primary and secondary data. Data was collected by distributing questionnaires using a Likert scale.

\section{RESULT AND DISCUSSION}

In this study, the respondents were $170 \mathrm{KFC}$ customers in Padang City, of which only 151 people met the requirements for the research. Where there were 19 people who visited KFC in the last 1 year less than 2 times, 44 people 2-5 times, 70 people 6-10 times, and 37 people> 10 times. Consisting of 60 men and 110 women. Respondents aged 16-20 years 10 people 21-25 years 151 people, $26-30$ years 7 people and $\geq 30$ years were 2 people. In terms of occupation, respondents consist of 10 civil servants, 39 private employees, 119 students and 2 others. This study using the test withthe partial least square structural equation modeling (SEMPLS) approach using the SmartPLS version 3.0 software. If the loading factor is above 0.5 against the intended construct, then the indicator can be said to be valid. The following is the SmartPLS Output for loading factors after eliminating invalid indicators:

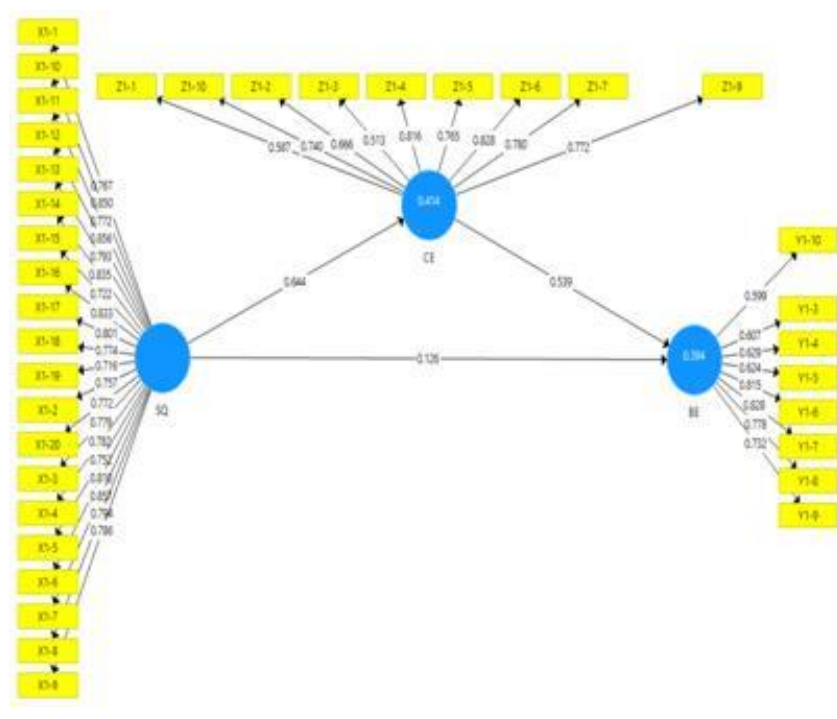

\section{Figure 1. SEM -PLS}

There are two steps taken to measure the evaluation of discriminant validity, the first is by looking at the value of cross loadings and the second by comparing the correlation between the construct and the AVE root. In table 1, it can be seen that the loading factor for other constructs is lower than the loading factor for each indicator for the construct. The square root of average variance extracted (AVE) method is another way to see discriminant validity with values above 0.5. In table 2, the AVE value in this study shows:
Table 1. Cronbach's Alpha

\begin{tabular}{|l|l|l|l|l|}
\hline & $\begin{array}{l}\text { Cronbach } \\
\text { alpha }\end{array}$ & Rho-a & reliability & AVE \\
\hline $\begin{array}{l}\text { Service } \\
\text { quality }\end{array}$ & 0.968 & 0.971 & 0.626 & \\
\hline $\begin{array}{l}\text { Customer } \\
\text { engagment }\end{array}$ & 0.885 & 0.907 & 0.526 & \\
\hline $\begin{array}{l}\text { Brand } \\
\text { experience }\end{array}$ & 0.854 & 0.887 & 0.501 & \\
\hline
\end{tabular}

The AVE value shown in table 1 is above 0.5 for all constructs contained in the research model. The lowest score for AVE is 0.501 in the Brand Experiences construct.

\subsection{Hipothesis Test}

In the following Path Coefficient table, it can be seen that the value of the correlation effect between constructs is used to test the hypothesis.

Table 2. Path Coefficient (Mean, STDEV, T-Values)

\begin{tabular}{|l|l|l|l|l|l|}
\hline & $\begin{array}{l}\text { Original } \\
\text { sample }\end{array}$ & $\begin{array}{l}\text { Sample } \\
\text { mean }\end{array}$ & STDEV & $\begin{array}{l}\text { (IO/ST } \\
\text { DEV) }\end{array}$ & Pvalue \\
\hline $\begin{array}{l}\text { SQ- } \\
\text { CE }\end{array}$ & 0.644 & 0.647 & 0.047 & 13.711 & 0 \\
\hline $\begin{array}{l}\text { SQ- } \\
\text { BE }\end{array}$ & 0.126 & 0.129 & 0.091 & 1.386 & 0.166 \\
\hline $\begin{array}{l}\text { SQ- } \\
\text { CE- } \\
\text { BE }\end{array}$ & 0.347 & 0.351 & 0.054 & 6.379 & 0 \\
\hline $\begin{array}{l}\text { CE- } \\
\text { BE }\end{array}$ & 0.539 & 0.541 & 0.076 & 7.093 & 0 \\
\hline
\end{tabular}

Furthermore, based on the structural model test, it shows a significant effect between SQ on CE, because it has a t-statistic value of 13.711 (> 1.96). 0.644 is the estimate value original sample indicating that the direction of the relationship between $\mathrm{SQ}$ and CE is positive. Thus the second hypothesis (H1) in this study which states that there is a positive and significant effect of Services Quality on Customer Engagement can be accepted.This finding is also reinforced by research conducted which states that Service Quality can improve Customer Engagement. According to quality service during and each meeting improves customer experience with brands which ultimately leads to emotional bonds such as customer engagement behavior and brand experiences with brands which are then manifested in purchasing, referring, and spreading word-of-mouth communication.

Furthermore, based on the structural model test, it shows no effect on the relationship between SQ and BE because the t-statistic value results in a value of 1.386 (<1.96), 0.126is the estimate value original sample indicating that the direction of the relationship between $\mathrm{SQ}$ and BE is positive. Thus the second hypothesis (H2) in this study which states that Services Quality has a positive effect on Brand Experiences accepted, and has 
an significant effect.The findings of this study are supported by the results of research conducted with results which show that Services Quality does not have a significant effect and shows a negative relationship with brand experiences. Based on the results of research on the influence of Services Quality on Brand Experiences, which shows that KFC customers in Padang City feel that the services provided by KFC in Padang City do not improve their experience when eating in place or take-away.

Next, Table 2 shows indirect effect between Services Quality on Brand Experiences through Customer Engagement, with a t-statistic value of 6.379 (> 1.96) and the original sample value is 0.347 which means positive.The outcomes of this observe are according with the outcomes of studies performed by [7], there is a significant affectamong Sevice Quality and Brand Experiences mediated through Customer Engagement. When customers give something to the company, customers will think about what they can take from the exchange [15]. By doing so, they're expected to reciprocate via way of means of presenting lower back price to the company and stimulating customer engagement [16].Service Quality in the course of and each assembly complements the customer experience with the brand which ultimately leads to emotional bonds which includes customer engagement behavior and brand experiences with brands which might be finally manifested in purchasing, referring, and spreading word of mouth [17]. Thus the third hypothesis (H3) can be accepted.

Furthermore, based on the structural model test, it shows a significant impactin the relationship between Customer Engagement to Brand Experiences, with a tstatistic value of $7.093(>1.96)$ and the original sample value of 0.539 which means positive. Thus the fourth hypothesis (H4) which states that there is a positive and significant impactof Customer Engagement on Brand Experiences maybe accepted.The results are in accordance with the results of research conducted where there is a significant impacton amongCustomer Engagement and Brand Experiences. argue that brand experiences are created through positive censorship arising from stimulation given to customers in an attractive and more engaging way of engaging customers with brands. The customer experience will be more attractive the more customer involvement in the brand, of course.

\section{CONCLUSIONS}

The conclusions of this study: (1). There is a direct influence on among Service Quality and Customer Engagement on KFC Customers in Padang City. This shows that the better the services provided by KFC employees in Padang City, the higher the involvement of KFC customers in Padang City. (2). There is no influence between Service Quality and Brand
Experiences on KFC Customers in Padang City. This shows that KFC customers in Padang City feel that the services provided by KFC in Padang City do not improve their experience when eating at the place or take-away. (3). There is an indirect relationship between Services Quality and Brand Experiences for KFC customers in Padang City through Customer Engagement. This shows that the presence of Customer Engagement mediation variables strengthens the influence of Services Quality on Brand Experiences. This means that Customer Engagement will positively mediate between the influence of Services Quality on Brand Experiences on KFC customers in Padang City. (4). There is a direct influence between Customer Engagement with Brand Experiences on KFC Customers in Padang City. This shows that the better the engagement between customers and KFC employees in Padang City, the higher the experience of KFC customers in Padang City.

\section{REFERENCES}

[1] K. Alexandris,, Dimitriadis, N., \&Markata, D. (2002). Can perceptions of Services Quality predict behavioral intentions? An exploratory study in the hotel sector in Greece. Managing Services Quality: An International Journal, 12(4), 224-231.

[2] L.Berry L. and Parasuraman, A. (1991), Marketing Service: Competing Through Quality, The Free Press, New York, NY.

[3] W. Staelin, R., Ehret, M., Johnston, W. J., Berry, L., Deighton, J., ... Bolton, R. N. (2005). Management Roadmap: What Is Known, Potential Pitfalls. Journal of Marketing, 69(November 2015),155-166.

[4] J. Schmitt, B. H., \&Zarantonello, L. (2009). Brand Experiences: What is It? How is it Measured? Does it Affect Loyalty? Journal of Marketing, 73(3),52-68.

[5] D. Shu, X. and Gan, C. (2014), "Mobile communications: a comprehensive hierarchical modeling approach", Asia Pacific Journal of Marketing and Logistics, Vol. 26 No. 1, pp. 114 146.

[6] D. Đorđević, D., \&Sajfert, Z. (2011). Customer Satisfaction and Acceptance of Relationship Marketing Concept: An Exploratory Study in QM Certified Serbian Companies. Organizacija, 44(2), 32-46. https://doi.org/10.2478/v10051-011-0004-y

[7] J. Cronin, J.J., Brady, M.K., Hult, G.T.M., 2000. Assessing the effects of quality, value, and customer satisfaction on consumer behavioral 
intentions in service environments. J. Retail. 76 (2), 193-218.

[8] L. Hollebeek D., \&Macky, K. (2019). Digital Content Marketing's Role in Fostering Customer Engagement, Trust, and Value: Framework, Fundamental Propositions, and Implications. Journal of Interactive Marketing, 45(February), 27-41.

[9] J. Islam U., Hollebeek, L. D., Rahman, Z., Khan, I., \& Rasool, A. (2019). Customer Engagement in the service context: An empirical investigation of the construct, its antecedents and consequences. Journal of Retailing and Consumer Services, 50(May),277-285.

[10] Y. Eisenberger, R., Baik, K., 2016. Perceived organizational support and affective organizational commitment: Moderating influence of perceived organizational competence. J. Organ. Behav. 37 (4), 558-583.

[11] V. Aksoy, L., Donkers, B., Venkatesan, R., Wiesel, T., \&Tillmanns, S. (2010). Undervalued or overvalued customers: Capturing total Customer Engagement value. Journal of Service Research, 13(3),297-310.

[12] C. Hollebeek, \& Mason, K. (2014). Customer experience - An analysis of the concept and its performance in airline brands. Research in Transportation Business and Management, 10, 1525. https://doi.org/10.1016/j.rtbm.2014.05.004

[13] M., Mubaya, T. R., van Reisen, M., \& van Stam, G. (2016). Maslow's Theory of Human Motivation and its Deep Roots in Individualism: Interrogating Maslow's Applicability in Africa. Theory, Knowledge, Development and Politics: What Role for the Academy in the Sustainability of Africa?, (May), 55-72.

[14] R. Mohamed N., Management, F. B., Mara, U. T., \& Musa, R. (2012). Disentangle the Effects of Brand Experiences (BE) on Trust, Commitment and Resonance: Evidence from Popular Fast Food Chain Restaurants in Malaysia: Using Structural Equation Modelling Approach, 1-22.

[15] A. Zeithaml, V.A. and Berry, L.L. (1988), "SERVQUAL: a multiple item scale for measuring consumer perception of Services Quality", Journal of Retailing, Vol. 64 No. 1, pp. 12-40.

[16] M. Swapana,, \&Padmavathy, C. (2017). - a Conceptual Model and Implications. 11(1).

[17] Zeithaml, V.A., Berry, L.L., Parasuraman, A., 1996. The behavioral consequences of Services Quality. J. Mark. 60 (2), 31-46. 